\title{
Research fields, challenges and opportunities in European oilseed crops breeding
}

\author{
Patrick Vincourt ${ }^{\star}$ \\ Open Source Biology, 12 Avenue Victor Segoffin, 31400, Toulouse, France
}

Received 3 October 2014 - Accepted 9 October 2014

\begin{abstract}
Due to the geographical specialization in oilseed world production, Europe has a major role to play in winter oilseed rape and sunflower breeding. Mainly based on the most recen t results, this review aims to identify the main research and breeding targets for these two crops, as seen through publications, with an attempt to suggest what are opportunities and challenges in these research fields. Growing a healthy and yielding crop remains the key driver for agronomic production. However sustainability and environmental profiles of the cultivar are now entering the field of play: The sustainability concern invested the field of resistance to diseases. Nitrogen use efficiency became an important target for Brassica napus, and crop resilience toward drought stresses is the way chosen in Helianthus annuus breeding for yield improvement. Significant advances are underway for quality traits, but the uncertainty on nutritional and industrial demand may explain why the product diversification remains low.
\end{abstract}

Keywords: Brassica napus / Helianthus annuus / breeding target / biotic / abiotic

Résumé - Champs de recherche, défis et opportunités de la sélection variétale des oléagineux européens. En raison de la spécialisation géographique dans la production mondiale d'oléagineux, l'Europe joue un rôle majeur dans la sélection de colza d'hiver et de tournesol. Reposant principalement sur les derniers résultats disponibles, cette revue cherche à identifier les principaux objectifs de recherche et de sélection de ces deux cultures, au regard des publications, et tente de suggérer quels sont les opportunités et défis de ces domaines de recherche. Faire croître des cultures saines et à haut rendement demeure un objectif clef de la production agronomique. Cependant la durabilité et les profils environnementaux de la variété cultivée entrent maintenant en ligne de compte : la préoccupation de durabilité a investi le champ de la résistance aux maladies. L'efficacité de l'utilisation de l'azote est devenu un objectif important pour Brassica napus, et la résistance des cultures au stress hydrique est l'une des voies majeures retenues pour la sélection chez Helianthus annuus. Des progrès significatifs sont en cours pour améliorer les traits qualitatifs, mais l'incertitude de la demande nutritionnelle et industrielle peut expliquer pourquoi la diversification de la production reste faible.

Mots clés : Brassica napus / Helianthus annuus / sélection / facteur biotique / facteur abiotique

\section{Introduction}

The world demand in oilseed derived products - oil and meal - continues to be boosted by the Asian developing countries, and the world oilseed production was expected to reach its all-time high in 2013-2014 (FAO, 2014). The area cultivation of the first four oilseed crops (soybean, rapeseed, palm oil and sunflower) is actually highly specialized according to

^ Correspondence:

patrick.vincourt@open-source-biology.com their overall agronomic adaptation (Fig. 1): for example, while Brazil and Argentina are the two main contributors for soybean production, the oilseed rape (WOSR) Brassica napus and the sunflower Helianthus annuus are playing the most important role within the geographical Europe. Beside of the agronomic adaptation of a given crop, the development of agricultural production is also modulated by the public policies, which impact both the targets for research and development and the financial support devoted to these targets. For example, today, the concerns about the sustainability of agricultural production are not 


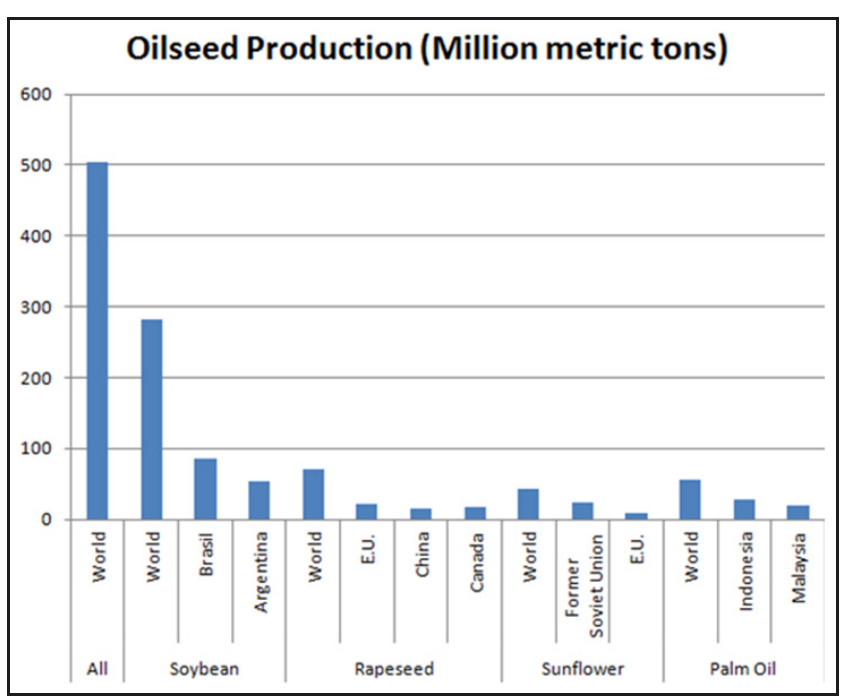

Fig. 1. World main oilseed productions (Source: USDA, http://apps. fas.usda.gov/psdonline/psdHome.aspx, 2013-2014 preliminary data, date: September 11, 2014). For each crop, the two or three main contributing countries are represented.

the same all around the world, and these concerns have a strong impact on the targets of plant breeding. Beside of this, there is a general trend, particularly in developed countries, to preferentially allocate research funds to already well established R\&D projects. Thus, these projects are benefiting both from the private companies financial effort and lobbying, and from the public sector. This trend may impact the potential of both efficiency and innovation. Focusing on the two main oilseed crops in Europe (WOSR and sunflower) and on the most recent advances, this short review aims to highlight (i) what are the key breeding targets, (ii) for each of them, what are the biggest challenges and opportunities in the next future.

\section{Growing a healthy and high yielding crop}

In their prospective study on oilseed crops competitiveness in the future, Sebillotte et al. (2002) highlighted seven strategic fields, thereafter exemplified in groups of scenarios. Four of them clearly pointed out key research fields for oilseed genetic improvement: oil quality according to the nutritional recommendations, meal quality according to animal feeding models, consumption of agricultural inputs according to environmental challenge, non-food uses. Nevertheless, and without any a priori contradiction with in any of these scenarios, growing a healthy and high yielding crop remains the main target for breeders, growers, and all the other stakeholders.

More and more research works are pointing out the interconnections between the plant responses to abiotic and biotic stresses (Kangasjarvi et al., 2014, Kissoudis et al., 2014). For example, identifying how the regulation of hormones (O'Brien and Benkova, 2013) could play the role of a hub in these interconnections is certainly an opportunity and a challenge, with consequences for plant breeding. However we will distinguish below these two types of interactions.

\subsection{Resistance to diseases: the arm race}

Looking back at the crop histories, and according to the evolutionary aspects of these interactions, (Van de Wouwe et al., 2014, Ahmed et al., 2012), blackleg due to the necrotrophic fungus Leptosphaeria maculans/Phoma linguam in oilseed rape and downy mildew of sunflower due to the oomycete Plasmopara halstedii (Gascuel et al., 2014), an obligate parasite, are probably the most threatening diseases in a long term arm race. Despite of the strong differences in the life style of the two pathogens, the interactions between them and the crops present some similarities. Indeed, in each case, both qualitative, genotype specific interactions - and their overcoming by new virulent pathotypes - and quantitative, non genotype specific interactions were found (Brun et al., 2010, Jestin et al., 2011, Tourvielle et al., 2008, Vear et al., 2008). Consequently, the scenarios to make the best use of the available genetic diversity together with participatory practices (Hossard et al., 2013, Tourvieille et al., 2005) might present some convergences.

The related parasitic species from the genus Orobanche/Phelipanche (O. cumana for sunflower, $P$. ramosa for oilseed rape) became during the last years a major concern, with very different patterns depending on the crop. Indeed, the resistance of sunflower to $O$. cumana has been a breeding target for a long time around the Mediterranean Sea and the Black Sea, but until recently (2009, source CETIOM) was not detected in France. Even if the genetic control of sunflower resistance became unclear through the wide diversification of the interaction patterns, non elucidated resistance mechanisms from cultivated or wild Helianthus genetic resources are currently exploited in breeding (Velasco et al., 2012). During the last years, a specific research effort was devoted to analyze the genetic diversity of the parasite (Molinero-Ruiz et al., 2014, Pineda-Martos et al., 2014) and to decipher the genetic of its virulence (Rodriguez-Ojeda et al., 2013). Strong progress was also made in the field of signaling between the plant and the parasite (Joël et al., 2011, Raupp and Spring, 2013). All of these knowledge are clearly needed when the purpose is to understand the complexity of this \{plant *parasite $\}$ interaction. An alternative solution (herbicide resistance) has been deployed in several countries. However, the sustainability of such alternative is questionable, particularly because of the multiplication rate of $O$. cumana, and because the mutations in the genes involved in the interaction with the chemical compounds used in herbicide treatment are frequent in plants (see http://www.open-source-biology.com/synthese_ALS.htm in French, for review). P. ramosa also recently appeared in French oilseed rape fields. In contrast with sunflower, until recently, B. napus was considered as exhibiting a poor genetic variation for resistance to this parasite. However, a variability in quantitative resistance at different stages of the \{plant* parasite $\}$ interaction has been found (Gauthier et al., 2012). Moreover, reminding that the glucosinolate pathway has been altered during the last four decades with the purpose of obtaining low-glucosinate content in the seed, it has been shown (Auger et al., 2012) that the stimulation of P. ramosa seed germination could be promoted by the glucosinolate metabolic pathway. Overall, aiming to solve by sustainable 
ways the susceptibility of sunflower and oilseed rape to these two plant parasites appears a key target for breeding.

Sclerotinia sclerotiorum is also a threat for both oilseed rape and sunflower. Because there was a possibility to solve this threat by chemical application in oilseed rape, the genetic resistance was previously not considered as a major target for this crop, until resistance to this chemical compound appeared in isolates of the pathogen. In the renewed context of agricultural policy aiming to reduce drastically the chemical inputs, the resistance to $S$. sclerotiorum in rapeseed became a target of stronger interest (Uloth et al., 2013). Beside of intrinsic varietal resistance, biological control with some strains of $B$. subtilis in seed coating might also be of interest (Hu et al., 2011, 2014).

There are obviously a number of other biological threats for oilseed rape and sunflower cultivation in Europe: Phoma macdonaldii, a cousin of Phoma linguam, is the pathogen causing also the blackleg disease in sunflower fields, with a particular impact when infesting the fields at a quite late developmental stage to induce the premature ripening (Seassau et al., 2010). Research and breeding programs have been developed with the aim to develop WOSR resistance toward clubroot caused by Plasmodiophora brassicae (Wagner et al., 2012). Genetic solutions, as well as crop management practices (Desanlys et al., 2013) were successfully developed from 1985 to make the sunflower fields poorly affected or even nearly resistant to Phomopsis due to Diaporthe helianthi. Resistance to the verticillium wilt caused by Verticillium dahliae is becoming an important sunflower breeding target in France.

All together, it means that beside of (or included in) the strategic orientations derived from prospective studies, a continuous effort should be devoted to keep the crops healthy by creating resistant cultivars. During the last years, due to the need of reducing the chemical inputs in crop production and also to concentrate $R \& D$ efforts on other targets than replacing a resistant gene by another, more and more attention was paid to the strategies aiming to develop sustainable resistance to diseases (Palloix et al., 2009, Quenouille et al., 2014). There is obviously no general strategy, as it depends on several intricate factors like the dynamic of evolution of virulence factors, the diversity of resistance genes deployed in a given cultivation area, the possibility to make the crop escaping its interaction with the pathogen through background traits, etc. Therefore, the challenge in this area would be to develop knowledge in the field of molecular genetics - to identify the virulence effectors - (As-sadi et al., 2011 for sunflower downy mildew, Zander et al., 2014 and Balesdent et al., 2014 for oilseed rape blackleg), of evolutionary genetics - to learn how these virulence patterns can evolve -, and finally of modeling, to ultimately predict how the $\{$ plant $*$ pathogen $\}$ interaction could evolve too.

\subsection{Yield: "Produce more with less"?}

As for other crops and traits, the availability of massive sequence data made possible the linkage mapping and increasingly the linkage disequilibrium (LD) mapping (the so called "association study") of QTL involved in yield and its components in WOSR and in sunflower. However, the key question remains: in which environmental conditions i.e. under which selection pressure these QTL have been discovered. Due to environmental constraints on agriculture, two targets are of crucial interest. In WOSR, nitrogen fertilization, a non renewable input, represents the major operational cost for growers (Orsel et al., 2014). The improvement of nitrogen use efficiency (NUE) is therefore a key target as far as WOSR yield increase or stability remains the overall objective of crop production. As a summer crop mainly grown in southern part of Europe, the sunflower is often faced to drought stresses during the vegetative growth and/or the grain filling period. The target is there to improve the overall crop resilience across a wide set of environments where the drought stress can occur at different developmental stages.

As differences in NUE were found between WOSR cultivar (Erley et al., 2011, Kessel et al., 2012), several research teams analyzed the differential responses to nitrogen fertilization $(N)$ in segregating populations. While Nyikako et al. (2014) found significant $\{$ genotype $* N\}$ interactions and concluded that breeding for improved NUE was possible, Bouchet et al. (2014) highlighted the fact that yield related mapped QTL were globally stable across $N$ regimes. This suggests that NUE improvement could be difficult. However, in that study, the range of $N$ stress was relatively limited. Research on NUE improvement in WOSR greatly benefited from studies on the model crop Arabidopsis thaliana (Chardon et al., 2012, Masclaux-Daubresse et al., 2010, Orsel et al., 2014), pointing out the need of more integrated translational research, i.e. from model crops to cultivated crops. The seven years collaborative project RAPSODYN is dedicated to this target (http://www. rapsodyn.fr/en/).

Like NUE, drought stress tolerance is a complex trait. From transcriptomic and morpho-physiological studies, Rengel et al. (2012) identified in sunflower, through a genenetwork approach, genes associated with physiological markers of the drought stress and whose expression was modulated by water stress both in controlled and field conditions. This subset of genes was thereafter considered to build a biomarker, based on expression data of three genes, indicating the water status of field grown sunflower plants (Marchand et al., 2014a). A gene regulatory network approach was used to identify, within a subset of genes responsive to drought stress, two hubs involved in transport nitrate in guard cells (Marchand et al., 2014b). LD mapping (Cadic et al., 2012) was also used to identify SNP associated with the yield response to a water stress indicator built thanks to the crop model SUNFLO (Casadebaig et al., 2011). The eight years SUNRISE collaborative project (http://www.sunrise-project.fr/en/) is particularly focusing on how the heterozygous status of sunflower cultivars could be more efficiently exploited to increase the crop resilience under a range of drought stresses.

A genome sequence of Brassica napus is now available (Chalhoub et al., 2014), and similar information should be soon available on Helianthus annuus (Kane et al., 2011). It is now generally considered that the limiting factor for gene and function discovery, and consequently tools for breeding, is becoming the acquisition of a precise and multivariate description of the phenotype (Cobb et al., 2013, Furbank and Tester, 2011). This is particularly true when complex and 
quantitative traits like NUE or response to drought stress are concerned. Different phenotyping tools have been developed in controlled conditions (Tisne et al., 2013). In sunflower, an intermediate tool (HELIAPHEN, Langlade et al., unpublished data) aiming to phenotype with a robot a few thousands of individual plants grown in pots in natural conditions has been realized. High throughput phenotyping in the field is also underway (Araus and Cairns, 2014). However, considering the cost of implementation of such tool in a single location, the good equilibrium between the number of locations - able to exhibit a range of $\{$ genotype $*$ environment interactions - and the depth of phenotyping in each location need to be finely tuned. Therefore, while the emergence of in depth phenotyping is a strong opportunity, the challenge is to elaborate tools allowing the integration of data from one scale (ex: growth chamber or glasshouse) to the other (ex: plots in the fields).

\section{Quality traits: diversification, a step ahead}

The oil part of oilseed crops represents the highest economic value of the production. As the broad sense heritability of seed oil content is relatively high in WOSR and in sunflower when compared to yield or other quantitative traits, it is relatively easy to obtain a genetic advance for this trait, for example when starting from a cross between "low" and "high" genotypes. Several QTL for oil content have been mapped in both crops (Bouchet et al., 2014, Delourme et al., 2006, Jiang et al., 2014, Merah et al., 2012). These results confirmed the highly polygenic nature of the trait. The average range of oil content in the seed is $41-48 \%$ in WOSR. Studying the grain structure of an ultrahigh oil content line $(65 \%)$, it has been reported (Hu et al., 2013) that it would be possible to increase this value up to $75 \%$ in oilseed rape.

With the advent of biotechnological approaches 25 years ago, several projects were intending to strongly modify the oil profile of crops, particularly in oilseed rape because of the fundamental knowledge provided on Arabidopsis thaliana and the possibility of genetic transformation in oilseed rape. The business aspect of this strategy was to dedicate some particular cultivar to a specific industrial use. As time went on, it appeared that this strategy was not really successful, for different reasons. However a diversification of the oil profiles took place, in WOSR as well as in sunflower, based on the use of mutants, mostly in or around fatty acid desaturase genes. In sunflower, the identification (Lacombe et al., 2001, 2009, Schuppert et al., 2006) of the mutation involved in the Pervenets source - a 40 years old genetic resource - allowed the faster development, through marker assisted selection, of cultivars with up to $88 \%$ of oleic acid in the oil. Several other mutants with modified oil profiles have been identified (Skorij et al., 2009), including high palmitoleic acid $(30 \%)$ and high stearic acid (30-35\%, Salas et al., 2014). Usually, the need in hard stock fats is solved by the hydrogenation of unsaturated fatty acids. A consequence of this industrial process is the production of unhealthy trans-fatty acids. It appeared therefore of interest to stack the two mutants (high stearic - high oleic, so-called "HSHO"), and such cultivar has been developed. The stearic acid content of the marketed product (Nutrisun ${ }^{\complement}$ ) is of $17 \%$ while the oleic acid content is of $70 \%$ (source: http://www. nutrisunoil.com/).
An ethyl methanesulphonate mutagenised population was developed in Brassica napus (Wells et al., 2014) to study the effect of mutations on fatty acid desaturases. One of these mutants had $6 \%$ of polyunsaturated fatty acids while the oleic acid content reached $84 \%$. Such profile was a long-standing target for the oil industry.

Other components of oil like tocopherols (Vitamine E) and phytosterols might be of interest for human nutrition. It was shown in sunflower that a genetic variability for their content could be exploited in breeding and QTL were mapped (Del Moral et al., 2012, Haddadi et al., 2011, Merah et al., 2012). The tocopherols B. napus orthologs of Arabidopsis genes were identified and functionally analyzed (Fritsche et al., 2014), providing precise tools for tocopherol profile modifications by breeding.

Oilseed rape and sunflower meals are by-products of these oil crops, but according to Sebillotte et al. (2002) should be taken into account in a prospective approach due to their interest for animal feeding to become a stronger alternative to soybean. In Brassica napus, QTL of seed color and fiber content (acid detergent lignin) were found co-localizing with candidate genes involved in the phenylpropanoid biosynthesis (Stein et al., 2013). More and more attention is paid to the industrial process allowing the sunflower seeds dehulling - and may be to the genetic variability of dehulling ability in the future as this should be a way to increase the size and the value of sunflower meal market.

All together, it appears that breeding for these traits could be easier than for yield and responses to biotic and abiotic stresses: rather high broad sense heritability, availability of mutants and of the genomic background making easier the identification of genes, molecular knowledge from model crops. To introduce a range of radically modified fatty acid profiles in cultivars is a priori a strong opportunity. The status of quality traits among the different breeding targets - with a relatively low weight in R\&D investments? - might be due to the uncertainty of nutritional and oil industry demand, as pointed out by Sebillotte et al. (2002).

\section{Conclusion}

The context of plant breeding activities changed a lot during the ten past years, with the availability of more and more genome sequences and related technologies, thus permitting an increase of the flux of gene function discovery. While this flux remains greater on model crops than in cultivated crops, some examples above show that translational research greatly facilitated the discovery in crops like $B$. napus due to the relatedness of $B$. napus with $A$. thaliana, but $A$. thaliana data were also very usefully involved in sunflower research. Except in some cases like maybe quality traits, this context does not modify the breeding priorities and/or opportunities, which derive from strategic choices and policies. Indeed, as above commented, the heritability of traits like yield or stress responses, or their genetic architecture, are the major limiting factor of genetic advance. With the development of genomic selection, one may wonder which weight will be devoted in the future to gene discovery and to "anonymous" QTL targeting. This might impact the global research organization (who is doing what?) in oilseed research as in other breeding programs. 


\section{References}

Araus JL, Cairns JE. 2014. Field high-throughput phenotyping: the new crop breeding frontier. Trends Plant Sci. 19: 52-61.

Auger B, Pouvreau JB, Pouponneau K, Yoneyama K, Montiel G, Le Bizec B, et al. 2012. Germination stimulants of Phelipanche ramosa in the rhizosphere of Brassica napus are derived from the glucosinolate pathway. Mol. Plant. Microbe Interact. 25: 993-1004.

Balesdent MH, Fudal I, Ollivier B, Bally P, Grandaubert J, Eber F, et al. 2013. The dispensable chromosome of Leptosphaeria maculans shelters an effector gene conferring avirulence towards Brassica rapa. New Phytol. 198: 887-898.

Bouchet AS, Nesi N, Bissuel C, Bregeon M, Lariepe A, et al. 2014. Genetic control of yield and yield components in winter oilseed rape (Brassica napus L.) grown under nitrogen limitation. Euphytica 199: 183-205.

Brun H, Chevre AM, Fitt BDL, Powers S, Besnard AL, Ermel M, et al. 2010. Quantitative resistance increases the durability of qualitative resistance to Leptosphaeria maculans in Brassica napus. New Phytol. 185: 285-299.

Cadic E, Debaeke P, Langlade L, Grezes-Besset B, Pauquet J, et al. 2012. Phenotyping the response of sunflower (Helianthus annuus L.) to drought scenarios in multi-environmental trials for the purpose of association genetics. Plant Animal Genome Int. Conf.

Casadebaig P, Guilioni L, Lecoeur J, Christophe A, Champolivier L, et al. 2011. SUNFLO, a model to simulate genotype-specific performance of the sunflower crop in contrasting environments. Agric. For. Meteorol. 151: 163-178.

Chalhoub B, Denoeud F, Liu SY, Parkin IAP, Tang HB, Wang X, et al. 2014. Early allopolyploid evolution in the post-Neolithic Brassica napus oilseed genome. Science 345: 950-953.

Chardon F, Noel V, Masclaux-Daubresse C. 2012. Exploring NUE in crops and in Arabidopsis ideotypes to improve yield and seed quality. J. Exp. Bot. 63: 3401-3412.

Cobb JN, DeClerck G, Greenberg A, Clark R, McCouch S. 2013. Next-generation phenotyping: requirements and strategies for enhancing our understanding of genotype-phenotype relationships and its relevance to crop improvement. Theor. Appl. Genet. 126: 867-887.

Del Moral L, Fernandez-Martinez JM, Velasco L, Perez-Vich B. 2012. Quantitative trait loci for seed tocopherol content in sunflower. Crop Sci. 52: 786-794.

Delourme R, Falentin C, Huteau V, Clouet V, Horvais R, Gandon $\mathrm{B}$, et al. 2006. Genetic control of oil content in oilseed rape (Brassica napus L.). Theor. Appl. Genet. 113: 1331-1345.

Desanlis M, Aubertot JN, Mestries E, Debaeke P. 2013. Analysis of the influence of a sunflower canopy on Phomopsis helianthi epidemics as a function of cropping practices. Field Crops Res. 149: 63-75.

Erley GSA, Behrens T, Ulas A, Wiesler F, Horst WJ. 2011. Agronomic traits contributing to nitrogen efficiency of winter oilseed rape cultivars. Field Crop Res. 124: 114-123.

FAO, Oilcrops, oils and meals market assessment - May 2014 http:// www.fao.org/economic/est/est-commodities/oilcrops/en/.

Fritsche S, Wang XX, Nichelmann L, Suppanz I, Hadenfeldt S, et al. 2014. Genetic and functional analysis of tocopherol biosynthesis pathway genes from rapeseed (Brassica napus L.) Plant Breed. 133: 470-479.

Furbank RT, Tester M. 2011. Phenomics - technologies to relieve the phenotyping bottleneck. Trends Plant Sci. 16: 635-644.

Gascuel Q, Martinez Y, Boniface MC, Vear F, Pichon M, et al. 2014. The sunflower downy mildew pathogen Plasmopara halstedii Mol. Plant Pathol. (accepted).
Gauthier M, Veronesi C, El-Halmouch Y, Leflon M, Jestin C, et al. 2012. Characterisation of resistance to branched broomrape, Phelipanche ramosa, in winter oilseed rape. Crop Prot. 42 : 56-63.

Haddadi P, Ebrahimi A, Langlade NB, Yazdi-samadi B, Berger M, et al. 2012. Genetic dissection of tocopherol and phytosterol in recombinant inbred lines of sunflower through quantitative trait locus analysis and the candidate gene approach. Mol. Breed. 29: 717-729.

Hossard L, Jeuffroy MH, Pelzer E, Pinochet X, Souchere V. 2013. A participatory approach to design spatial scenarios of cropping systems and assess their effects on phoma stem canker management at a regional scale. Environ. Model. Soft. 48: 17-26.

Hu ZY, Hua W, Zhang L, Deng LB, Wang XF, Liu GH, et al. 2013. Seed structure characteristics to form ultrahigh oil content in rapeseed, PLoS One 8: e62099.

Hu XJ, Roberts DP, Xie LH, Maul JE, Yu CB, Li YS, et al. 2014. Formulations of Bacillus subtilis BY-2 suppress Sclerotinia sclerotiorum on oilseed rape in the field. Biol.Control 70: 54-64.

Hu XJ, Roberts DP, Maul JE, Emche SE, Liao X, Guo X, et al. 2011. Formulations of the endophytic bacterium Bacillus subtilis Tu100 suppress Sclerotinia sclerotiorum on oilseed rape and improve plant vigor in field trials conducted at separate locations. Can. J. Microbiol. 57: 539-546.

Jiang CC, Shi JQ, Li RY, Long Y, Wang H, Li D, et al. 2014. Quantitative trait loci that control the oil content variation of rapeseed (Brassica napus L.). Theor. Appl. Genet. 127: 957-968.

Joel DM, Chaudhuri SK, Plakhine D, Ziadna H, Steffens JC. 2011. Dehydrocostus lactone is exuded from sunflower roots and stimulates germination of the root parasite Orobanche cumana Phytochem. 72: 624-634.

Kane NC, Gill N, King MG, Bowers JE, Berges H, et al. 2011. Progress towards a reference genome for sunflower. Botany 89: 429-437.

Kangasjarvi S, Tikkanen M, Durian G, Aro EM. 2014. Photosynthetic light reactions - An adjustable hub in basic production and plant immunity signaling. Plant Physiol. Biochem. 81: 128-134.

Kessel B, Schierholt A, Becker HC. 2012. Nitrogen use efficiency in a genetically diverse set of winter oilseed rape (Brassica napus L.). Crop Sci. 52: 2546-2554.

Kissoudis C, van de Wiel C, Visser RGF, van der Linden G. 2014. Enhancing crop resilience to combined abiotic and biotic stress through the dissection of physiological and molecular crosstalk. Front. Plant. Sci. 5: 207.

Jestin C, Lode M, Vallee P, Domin C, Falentin C, Horvais R, et al. 2011. Association mapping of quantitative resistance for Leptosphaeria maculans in oilseed rape (Brassica napus L.). Mol. Breed. 27: 271-287.

Marchand G, Huynh-Thu VA, Kane N, Arribat S, Varès D, Rengel D, et al. 2014. Bridging physiological and evolutionary time scales in a gene regulatory network. New Phytol. 203: 685-696.

Marchand G, Mayjonade B, Varès D, Blanchet N, Boniface MC, Maury P, et al. 2013. A biomarker based on gene expression indicates plant water status in controlled and natural environments. Plant Cell Envir. 36: 2175-2189.

Masclaux-Daubresse C, Daniel-Vedele F, Dechorgnat J, Chardon F, Gaufichon L, et al. 2010. Nitrogen uptake, assimilation and remobilization in plants: challenges for sustainable and productive agriculture. Ann. Bot. 105: 1141-1157.

Merah O, Langlade N, Alignan M, Roche J, Pouilly N, Lippi Y, et al. 2012. Genetic analysis of phytosterol content in sunflower seeds Theor. App. Genet. 125: 1589-1601. 
Molinero-Ruiz L, Garcia-Carneros AB, Collado-Romero M, Raranciuc S, Dominguez J, et al. 2014. Pathogenic and molecular diversity in highly virulent populations of the parasitic weed Orobanche cumana (sunflower broomrape) from Europe. Weed Res. 54: 87-96.

Nyikako J, Schierholt A, Kessel B, Becker HC. 2014. Genetic variation in nitrogen uptake and utilization efficiency in a segregating DH population of winter oilseed rape Euphytica 199: 3-11.

O'Brien JA, Benkova E. 2013. Cytokinin cross-talking during biotic and abiotic stress responses. Front. Plant Sci. 4: 451.

Orsel M, Moison M, Clouet V, Thomas J, Leprince F, et al. 2014. Sixteen cytosolic glutamine synthetase genes identified in the Brassica napus L. genome are differentially regulated depending on nitrogen regimes and leaf senescence J. Exp. Bot. 65: 39273947.

Palloix A, Ayme V, Moury B. 2009. Durability of plant major resistance genes to pathogens depends on the genetic background, experimental evidence and consequences for breeding strategies. New Phytol. 183: 190-199.

Pineda-Martos R, Velasco L, Perez-Vich B. 2014. Identification, characterisation and discriminatory power of microsatellite markers in the parasitic weed Orobanche cumana. Weed Res. 54: 120132.

Quenouille J, Paulhiac E, Moury B, Palloix A. 2014. Quantitative trait loci from the host genetic background modulate the durability of a resistance gene: a rational basis for sustainable resistance breeding in plant. Heredity 112: 579-587.

Raupp FM, Spring OJ. 2013. New sesquiterpene lactones from sunflower root exudate as germination stimulants for Orobanche cumana. Agric. Food Chem. 61: 10481-10487.

Rengel D, Arribat S, Maury P, Martin-Magniette ML, Hourlier T, Laporte M, et al. 2012. A gene-phenotype network based on genetic variability for drought responses reveals key physiological processes in controlled and natural environments. PLoS One 7: e45249.

Rodriguez-Ojeda MI, Pineda-Martos R, Alonso LC, FernandezEscobar J, Fernandez-Martinez JM, et al. 2013. A dominant avirulence gene in Orobanche cumana triggers Or5 resistance in sunflower. Weed Res. 53: 322-327.

Salas JJ, Martínez-Force E, Harwood JL, Venegas-Calerón M, AznarMoreno JA, et al. 2014. Biochemistry of high stearic sunflower, a new source of saturated fats Prog. Lipid Res. 55: 30-42.

Seassau C, Dechamp-Guillaume G, Mestries E, Debaeke P. 2010. Nitrogen and water management can limit premature ripening of sunflower induced by Phoma macdonaldii. Field Crops Res. 115: 99-106.
Sebillotte c, Messean A, Ruck L. 2002. Prospective " Compétitivité des oléagineux dans l'avenir" (Future study "The oilseed competitiveness in the future") OCL 9: 362-368.

Skoric D, Jocic S, Sakac Z, Lecic N. 2008. Genetic possibilities for altering sunflower oil quality to obtain novel oils. Can. J. Physiol. Pharmacol. 86: 215-221.

Stein A,Wittkop B, Liu LZ, Obermeier C, Friedt W, et al. 2013. Dissection of a major QTL for seed colour and fibre content in Brassica napus reveals colocalization with candidate genes for phenylpropanoid biosynthesis and flavonoid deposition. Plant Breed. 132: 382-389.

Tisne S, Serrand Y, Bach L, Gilbault E, Ben Ameur R, et al. 2013. Phenoscope: an automated large-scale phenotyping platform offering high spatial homogeneity. Plant J. 74: 534-544.

Tourvielle D, Mestries E, Walser P. 2005. Quelles perspectives pour la lutte génétique vis-à-vis du mildiou du tournesol? OCL 12 (2).

Uloth MB, You MP, Finnegan PM, Banga SS, Banga SK, et al. 2013. New sources of resistance to Sclerotinia sclerotiorum for crucifer crops. Field Crop Res. 154: 40-52.

USDA PSD online http://apps.fas.usda.gov/psdonline/psdHome. aspx.

Van de Wouw A, Marcroft SJ, Ware A, Lindbeck K, Khangura R, et al. 2014. Breakdown of resistance to the fungal disease, blackleg, is averted in commercial canola (Brassica napus) crops in Australia. Field Crops Res. 166: 144-151.

Vear F, Serre F, Jouan-Dufournel I, Bert PF, Roche S, et al. 2008. Inheritance of quantitative resistance to downy mildew (Plasmopara halstedii) in sunflower (Helianthus annuus L.) Euphytica 164: 561-570.

Velasco L, Perez-Vich B, Yassein AAM, Jan CC, Fernandez-Martinez JM. 2012. Inheritance of resistance to sunflower broomrape (Orobanche cumana Wallr.) in an interspecific cross between Helianthus annuus and Helianthus debilis subsp tardiflorus. Plant Breed. 131: 220-221.

Wells R, Trick M, Soumpourou E, Clissold L, Morgan C, Werner P, et al. 2014. The control of seed oil polyunsaturate content in the polyploid crop species Brassica napus. Mol. Breed. 33: 349-362.

Wagner G, Charton S, Lariagon C, Laperche A, Lugan R, Hopkins J, et al. 2012. Metabotyping: A new approach to investigate rapeseed (Brassica napus L.) genetic diversity in the metabolic response to clubroot infection. Mol. Plant. Microbe Interact. 25: 1478-1491.

Zander M, Patel DA, Van de Wouw A, Lai KT, Lorenc MT, et al. 2013. Identifying genetic diversity of avirulence genes in Leptosphaeria maculans using whole genome sequencing. Funct. Integr. Genomics: 13: 294-308. 